\title{
Hemidystonia: a report of 22 patients and a review of the literature
}

\author{
L CREED PETTIGREW, ${ }^{*}$ JOSEPH JANKOVIC $\dagger$ \\ From the Department of Neurology, University of Texas Health Science Center, ${ }^{*}$ and the Department of \\ Neurology, Baylor College of Medicine, Texas Medical Center, Houston, Texas, USA
}

SUMMARY Hemidystonia defined as involuntary, sustained posturing of the unilateral arm, leg, and face was studied in 12 male and 10 female patients. Hemidystonia was caused by cerebrovascular disease in eight patients, perinatal trauma or childhood injury in four, head trauma and its sequelae in three, neuronal storage disorders in two, neurodegenerative disease in two, lesions after thalamotomy in two, and presumed encephalitis in one. Sixteen patients (73\%) had CT evidence of contralateral basal ganglia damage, history of hemiparesis, or both. Brain damage before 7 years of age produced contralateral hemidystonia with a mean delay of 9-7 years. In older patients hemidystonia appeared within 6 months after injury. Hemidystonia may result from a disconnection between the striatum and the thalamus with relative preservation of the corticospinal pathways.

The term dystonia was coined by Oppenheim in 1911 to describe sustained posturing as well as tonic and clonic spasms of different parts of the body with muscle tone fluctuating between hypotonia and hypertonia.' ${ }^{1}$ Most patients with dystonia have primary torsion dystonia, which is either sporadic or hereditary. ${ }^{2-6}$ The biochemical and pathophysiological mechanisms of primary (idiopathic) dystonia are unknown. ${ }^{7-10}$ Dystonia rarely occurs as a psychiatric condition, although it is frequently misdiagnosed as such. ${ }^{11-13}$

Dystonia has been classified according to distribution as either focal, when only a single body part is involved (torticollis, blepharospasm, oromandibular dystonia, writer's cramp, or foot dystonia), multifocal or segmental, when more than one body part is involved, or generalised, indicating involvement of at least one leg and a cranial or a brachial structure. ${ }^{35614}$ Occasionally the unilateral arm, leg, and face are affected. This presentation has

Presented in part during the 109th annual meeting of the American Neurological Association, 8-10 October, 1984, Baltimore, Maryland.

Address for reprint requests: Joseph Jankovic, MD. Department of Neurology, Baylor College of Medicine, Texas Medical Center, Houston, Texas 77030, USA

Received 23 August 1984 and in revised form 14 November 1984. Accepted 17 November 1984 aetiologic significance and calls for a separate category of hemidystonia.

We describe 22 patients with acquired hemidystonia and propose a pathogenic mechanism for this disorder.

\section{Methods}

Three hundred and nine patients with dystonia, defined as involuntary sustained posturing, have been evaluated at the Baylor Movement Disorder Clinic from 1978 to 1984. Twenty-two patients $(7 \cdot 1 \%)$ had dystonia of the arm and leg on one side of the body and some had involvement of the neck or face (tables 1 and 2). None had generalised dystonia, positive family history, or Ashkenazi Jewish background. Patients with focal dystonia, Wilson's disease, Huntington's disease, Hälervorden-Spatz disease, and other hereditary neurological syndromes were excluded. There was no history of exposure to manganese, carbon monoxide, drugs, or other agents known to produce persistent dystonia. ${ }^{1516}$ All patients were filmed.

\section{Results}

There were 22 patients, 12 men and 10 women (table 1). The mean age at onset of hemidystonia was 36 years (range: 2 to 72 years). Eleven patients (50\%) had focal neurologic deficits prior to the onset of dystonia. The mean latency between the onset of focal signs and the appearance of abnormal posturing was 4 years. Patients 1 to 6 acquired cere- 
Table 1 Historical data on 22 patients with hemidystonia

\begin{tabular}{lll}
\hline Patient & $\begin{array}{l}\text { Age at onset of } \\
\text { dystonia (yr) }\end{array}$ & Predisposing factors and observations \\
No. & Handedness, Sex &
\end{tabular}

, Hondedness, Sex

Latency between Duration of disease Associated disorders predisposing brain at last follow-up insult and onset of $(y r)$ dystonia

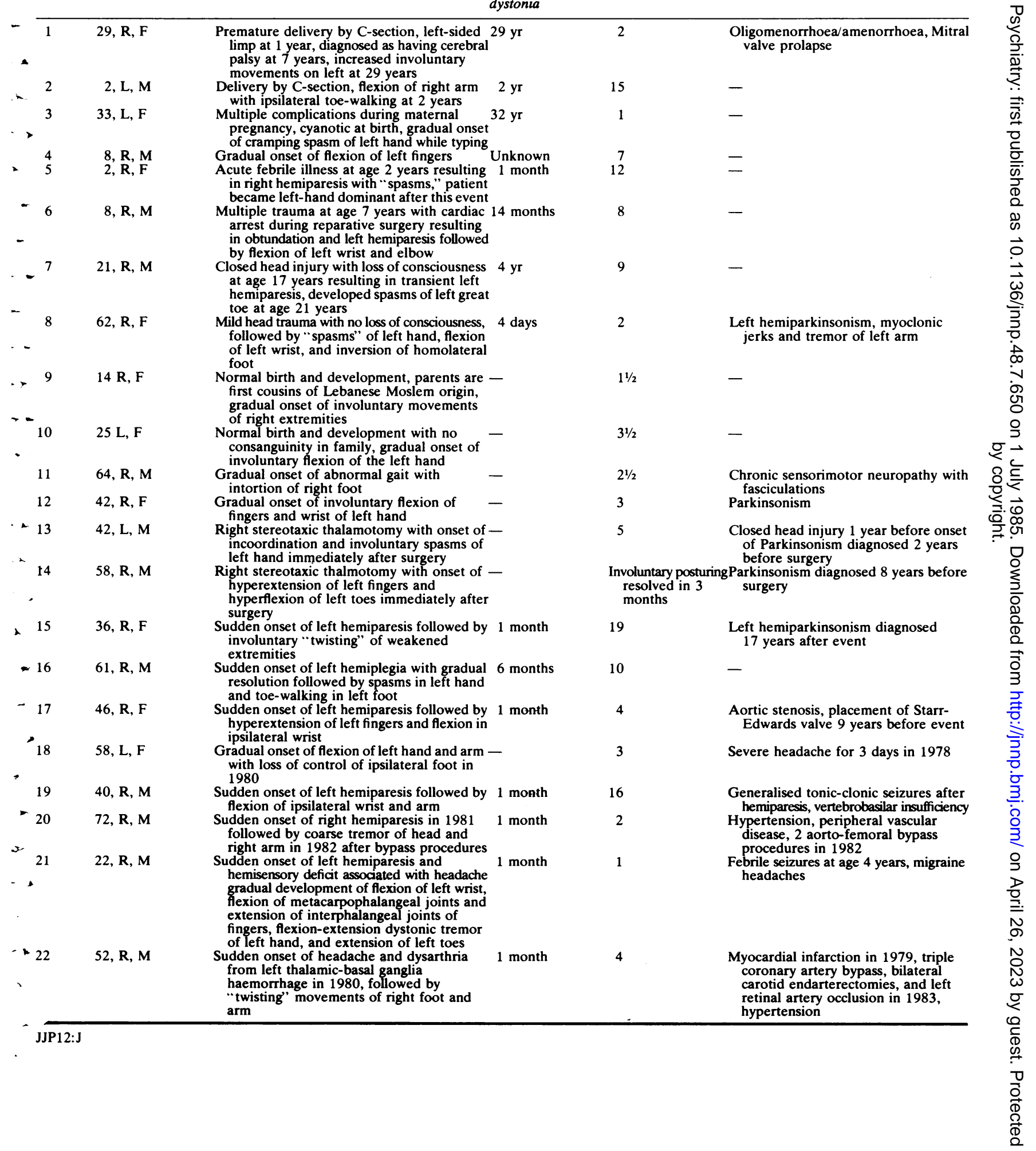


Table 2 Clinical characteristics of 22 patients with hemidystonia

\begin{tabular}{|c|c|c|c|c|c|c|}
\hline \multirow{2}{*}{$\begin{array}{l}\text { Patient } \\
\text { No. }\end{array}$} & \multirow{2}{*}{$\begin{array}{l}\text { Distribution of } \\
\text { dystonia }\end{array}$} & \multicolumn{2}{|l|}{ Neurodiagnostic procedures } & \multicolumn{3}{|l|}{ Therapy and results } \\
\hline & & $C T$ & Other & Medical & Surgical & 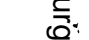 \\
\hline 1 & (L)AH, Fo & $\begin{array}{l}\text { Right cerebral atrophy, } \\
\text { arachnoidal cyst in right } \\
\text { frontoparietal area }\end{array}$ & $\begin{array}{l}\text { Angiogram showing avascular } \\
\text { mass corresponding to } \\
\text { arachnoidal cyst }\end{array}$ & $\begin{array}{l}\text { Subjective improvement with } \\
\text { Sinemet and baclofen }\end{array}$ & - & 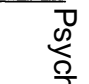 \\
\hline 2 & (R) AH, Fo & $\begin{array}{l}\text { Left cerebral atrophy, left } \\
\text { porencephalic cyst }\end{array}$ & $\begin{array}{l}\text { EEG with slowing in left } \\
\text { posterior region }\end{array}$ & $\begin{array}{l}\text { Subjective improvement with } \\
\text { baclofen and trihexyphenidyl }\end{array}$ & $1-$ & 总 \\
\hline 3 & (L)AH, Fo & $\begin{array}{l}\text { Linear area of infarction in } \\
\text { posterior right putamen }\end{array}$ & NC & $\begin{array}{l}\text { Subjective improvement with } \\
\text { trihexyphenidyl }\end{array}$ & - & 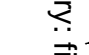 \\
\hline 4 & (L)AH, LF & Infarction in right basal ganglia & Normal cerebral angiography & $\begin{array}{l}\text { No response to Sinemet, } \\
\text { haloperidol, and ethopropazine }\end{array}$ & $\begin{array}{l}\text { Stereotax } \\
\text { right V } \\
\text { with re } \\
\text { within }\end{array}$ & 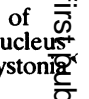 \\
\hline 5 & (R)AH, Fo & Infarction in left striatum & NC & $\begin{array}{l}\text { Subjective improvement with } \\
\text { trihexyphenidyl }\end{array}$ & $\begin{array}{l}\text { Triple ar } \\
\text { transfe }\end{array}$ & tendo $\frac{\sigma}{\frac{5}{T}}$ \\
\hline 6 & (L) AH, LF & Normal & NC & No response to multiple drugs & $\begin{array}{l}\text { Stereotax } \\
\text { ventral } \\
\text { right th } \\
\text { improv }\end{array}$ & $\begin{array}{l}\text { of } \\
\text { na of } \\
\text { ansiert, }\end{array}$ \\
\hline 7 & (L)AH, LF & $\begin{array}{l}\text { Encephalomalacia in right globus } \\
\text { pallidus }\end{array}$ & $\mathrm{NC}$ & No response to multiple drugs & $\begin{array}{l}\text { Stereotax } \\
\text { Vim th } \\
\text { mild in } \\
\text { hand } d\end{array}$ & $\begin{array}{l}\text { of right } \\
\text { with } \overrightarrow{\mid \overrightarrow{0}} \\
\text { left } \overrightarrow{\vec{J}}\end{array}$ \\
\hline 8 & (L)AH, Fo & $\begin{array}{l}\text { Enhancement in right posterior } \\
\text { thalamus, empty sella }\end{array}$ & $\Gamma{ }^{2} f_{1}$ & No response to Sinemet & - & 引ે \\
\hline 9 & (R)F, AH, LF & Minimal œrebral atrophy & $\begin{array}{l}\text { EM of lymphocytes positive for } \\
\text { ceroid inclusion bodies }\end{array}$ & $\begin{array}{l}\text { Subjective improvement with } \\
\text { trihexyphenidyl }\end{array}$ & - & 官 \\
\hline 10 & (L)AH, Fo & Normal & $\begin{array}{l}\text { Conjunctival biopsy showing } \\
\text { fibroblasts distended by } \\
\text { ceroid-engorged vacuoles }\end{array}$ & No response to multiple drugs & - & \\
\hline 11 & (R)AH, LF & Normal & $\begin{array}{l}\text { EMG/NCS showing sensory } \\
\text { neuropathy, muscle biopsy } \\
\text { showing fiber type grouping }\end{array}$ & $\begin{array}{l}\text { Subjective improvement with } \\
\text { Sinemet }\end{array}$ & & \\
\hline 12 & (L)H, Fo & Normal & NC & $\begin{array}{l}\text { Subjective improvement with } \\
\text { Sinemet }\end{array}$ & - & \\
\hline 13 & (L)H, Fo & Normal & NC & $\begin{array}{l}\text { No response to Sinemet, } \\
\text { trihexyphenidyl, and } \\
\text { amantadine }\end{array}$ & - & 을 \\
\hline 14 & (L)H, Fo & Normal & NC & $\begin{array}{l}\text { Resolution of dystonia following } \\
3 \text { months of treatment with } \\
\text { Sinemet and trihexyphenidyl }\end{array}$ & $g-$ & 글. \\
\hline 15 & (L)AH, LF & Infarction of right basal ganglia & NC & $\begin{array}{l}\text { No response to trihexyphenidyl } \\
\text { and benzodiazepine }\end{array}$ & - & \\
\hline 16 & (L)H, Fo & $\begin{array}{l}\text { Infarction of genu of right } \\
\text { internal capsule }\end{array}$ & NC & No response to trihexyphenidyl & - & \\
\hline 17 & (L)H, Fo & $\begin{array}{l}\text { Enhancement in area of previous } \\
\text { infarction in right basal ganglia }\end{array}$ & $\begin{array}{l}\text { sAngiogram showing embolic } \\
\text { occlusion of trifurcation of } \\
\text { right middle cerebral artery }\end{array}$ & No response to Sinemet & - & ֻ \\
\hline 18 & (L)AH, LF & $\begin{array}{l}\text { Encephalomalacia in right basal } 1 \\
\text { ganglia }\end{array}$ & $\mathrm{NC}$ & $\begin{array}{l}\text { No response to multiple } \\
\text { medications }\end{array}$ & - & \\
\hline 19 & (L)AH, Fo & $\begin{array}{l}\text { Infarction of right basal } \\
\text { ganglia }\end{array}$ & NC & $\begin{array}{l}\text { Subjective improvement with } \\
\text { trihexyphenidyl }\end{array}$ & - & \\
\hline 20 & (R)AH, Fo & Normal & $\begin{array}{l}\text { Palatal myoclonus documented } \\
\text { EMG }\end{array}$ & $\begin{array}{l}\text { No response to multiple } \\
\text { medications }\end{array}$ & & \\
\hline 21 & (L)H, Fo & $\begin{array}{l}\text { Encephalomalacia in area of } \\
\text { posterior limb of right internal } \\
\text { capsule }\end{array}$ & Normal œrebral angiography & $\begin{array}{l}\text { No response to propranolol or } \\
\text { trihexyphenidyl }\end{array}$ & - & 竞 \\
\hline 22 & (L), AH, LF & $\begin{array}{l}\text { Left thalamic-basal ganglia } \\
\text { haemonthage. in } 1980 \text {. Lucency } \\
\text { in external capsule extending } \\
\text { into striatum in } 1983\end{array}$ & $\begin{array}{l}\text { Cerebral angiography in } 1983 \\
\text { y showing } 60 \% \text { stenosis of both } \\
\text { common carotid arteries }\end{array}$ & $\begin{array}{l}\text { No response to haloperidol, } \\
\text { marked spontaneous } \\
\text { resolution over four years }\end{array}$ & - & \\
\hline
\end{tabular}

$\mathrm{R}=$ right, $\mathrm{L}=$ left, $\mathrm{M}=$ male, $\mathrm{AH}=$ arm-hand, $\mathrm{LF}=$ leg-foot, $\mathrm{Fo}=$ foot, $\mathrm{H}=$ hand, $\mathrm{F}=$ face, $\mathrm{NC}=$ noncontributory, $\mathrm{EM}=$ electron microscop $\mathrm{EMG} / \mathrm{NCS}=$ electromyography, nerve conduction studies

Trihexyphenidyl = benzhexol

bral insults before 7 years of age and had a mean latency of 9.7 years (range: 1 month to 32 years) from the acute injury to the onset of hemidystonia. Adult patients developed hemidystonia within 6 months after the predisposing injury.

The mean duration of dystonia was 6 years (range: 2 months to 19 years). The patients were followed an average of 2 years. Two patients (nos. 13 and 14) had been followed for Parkinson's disease for 2 and 8 years, respectively, before they developed hemidystonia after thalamotomy.

CT scans were performed on all 22 patients (fig $1 \mathrm{~A}-\mathrm{B}$ and $2 \mathrm{~B})$. Eleven patients $(50 \%)$ had evidence of basal ganglia damage on CT (tables 2 and 3). 

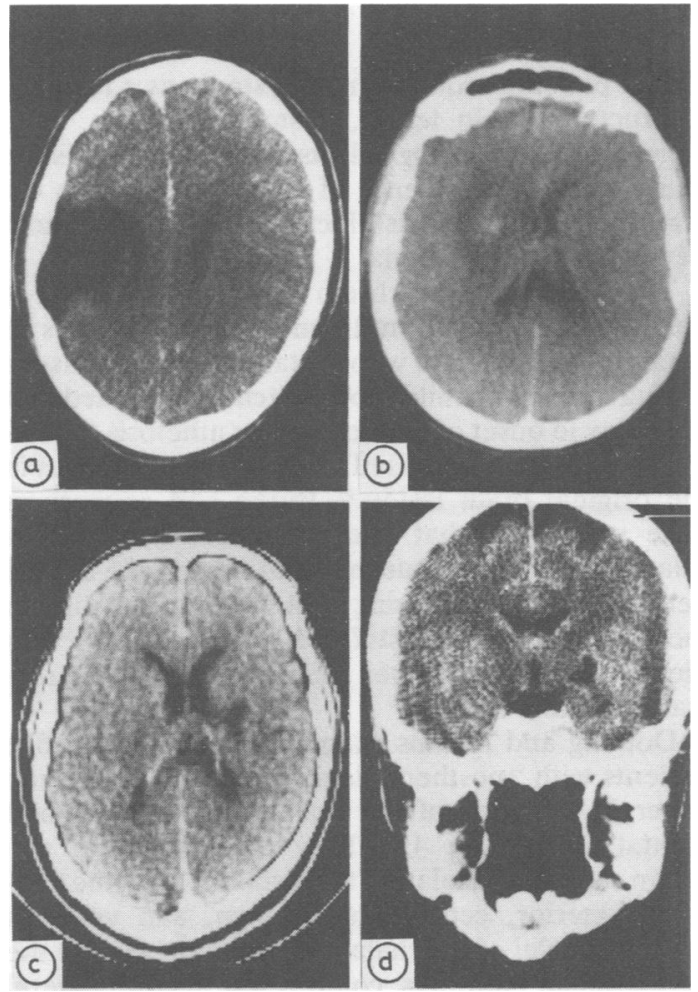

Fig 1 (A) Right cerebral atrophy and arachnoidal cyst in patient 1. (B) Contrast enhancement in area of embolic infarction in right basal ganglia in patient 17. (C) Infarction of genu of right internal capsule in patient 16. (D)

Post-traumatic encephalomalacia in the area of the right globus pallidus in patient 7.

Diffuse damage in the basal ganglia region contralateral to hemidystonia was present in seven patients (Nos. 1, 2, 4, 15, 17-19), and in 3 (Nos. 3, $5,22)$ the lesions were confined to the striatal nuclei, involving chiefly the putamen. Cerebral angiography showed an avascular mass corresponding to the location of the arachnoidal cyst in patient 1 , an embolic occlusion of the right middle cerebral artery in patient 17 , and bilateral carotid stenosis in patient 22. Electroencephalograms in nine patients were
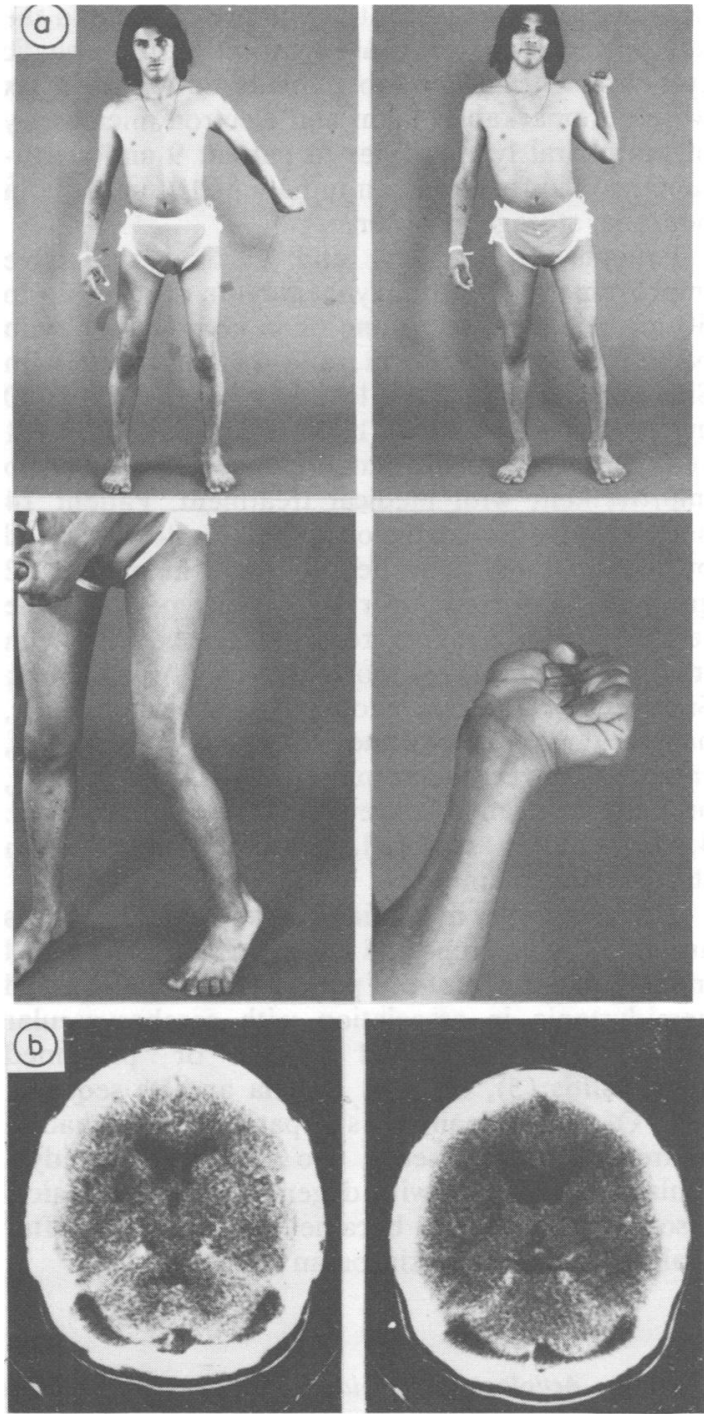

Fig 2 (A) Patient 4. Note abduction of the left arm at the shoulder with flexion or extension of the elbow, inversion of the ipsilateral leg and foot, and dystonic flexion of the left fingers. (B) Infarction of right basal ganglia and cerebellar hypoplasia in patient 4.

Table 3 CT scan in hemidystonia $(n=22)$

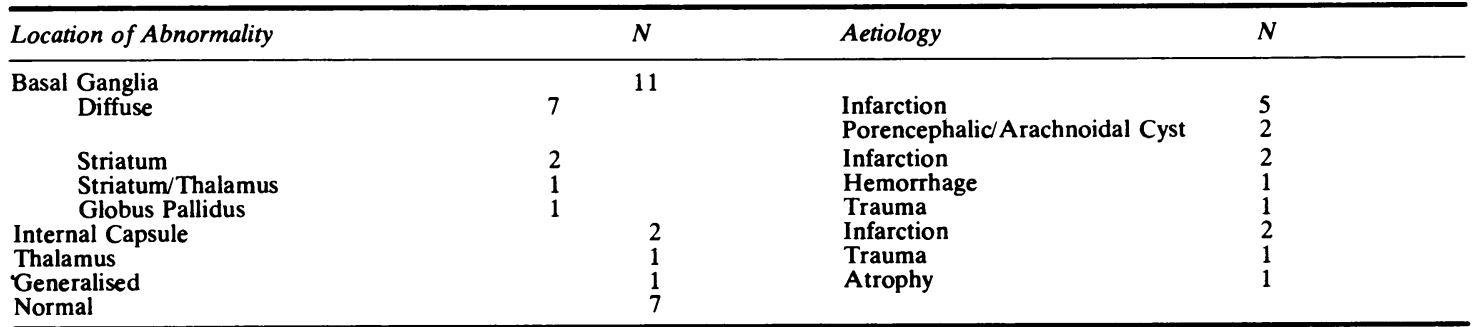


normal except for patient 2 who had slowing in the left posterior region caused by the porencephalic cyst. Myelograms in two patients and CSF in six were unremarkable. Light and electron microscopy of peripheral lymphocytes in patient 9 and a conjunctival biopsy specimen in patient 10 suggested a neuronal storage disorder.

Patients 2, 3, 5, 9, and 19 had subjective improvement with trihexyphenidyl in dosages up to $30 \mathrm{mg}$ per day used alone or in combination with baclofen. Patients 1, 11, and 12 improved with Sinemet (carbidopa and levodopa) up to $100 / 1000$ mg per day. In patient 1 this effect lasted only 1 year. Neurological examination revealed little or no improvement with medical treatment. Patient 14 had spontaneous remission of hemidystonia caused by thalamotomy. The hemidystonia in patient 22 gradually resolved over a 4-year period. The remaining 11 patients received no benefit from treatment with one or more of the following drugs: Sinemet (carbidopa/levodopa), trihexyphenidyl, haloperidol, tetrabenazine, reserpine, propranolol, clonazepam, carbamazepine, dantrolene sodium, orphenadrine, and clorazepate. Three patients (Nos. 4,6 , and 7) received transient benefit from stereotaxic thalamotomy.

The aetiologies of hemidystonia in the 22 patients and in 52 others reported in the literature are listed in table 4 . Sixteen of our patients $(72 \%)$ developed hemidystonia in association with cerebrovascular disease (8), childhood injury or presumed encephalitis (5), or head trauma and its sequelae (3). Of the remaining six patients, two had a neuronal storage disease, two developed hemidystonia in association with degenerative neurological disorders, and two became hemidystonic after thalamotomy for Parkinsonian tremor.

\section{Discussion}

All 22 patients acquired hemidystonia as a result of a structural brain lesion, a storage disease, or a degenerative neurological disorder. A pre-existing hemiparesis and evidence of striatal damage on CT scan were important risk factors for the subsequent development of dystonia.

The latency between brain injury and the onset of hemidystonia was from 14 months to 29 years in patients $1,2,3$, and 6 who sustained cerebral insults during infancy or childhood. Mitchell suggested that the delay in onset of hemichorea or athetosis following hemiplegia was caused by progressive changes in the original brain lesion. ${ }^{17}$ Burke and co-workers have speculated that "delayed-onset dystonia" is related to aberrant neuronal sprouting in the central nervous system following a static lesion. ${ }^{18}$ Similar mechanisms are postulated in patients with blepharospasm and other facial dystonias after rostral brainstem lesions. ${ }^{19}$

Dooling and Adams examined the brains of five patients with "posthemiplegic athetosis" and found generalised gliosis of the thalamus in 1 brain and striatal damage in $4 .{ }^{20}$ They suggested that any lesion capable of isolating the striatum from the ventralis anterior, centrum medianum, and ventralis lateralis nuclei of the thalamus, while preserving the corticospinal pathways, could result in contralateral involuntary movements. Although they used the term athetosis to describe these movements, a review of the case histories suggests that their patients had hemidystonia. Other reports provide additional evidence for the theory of striatopallido-thalamic disconnection (table 4). All but five of the 35 reported cases of hemidystonia had focal lesions of the striatal nuclei by radiographic studies

Table 4 Aetiologies of hemidystonia: present series and literature review

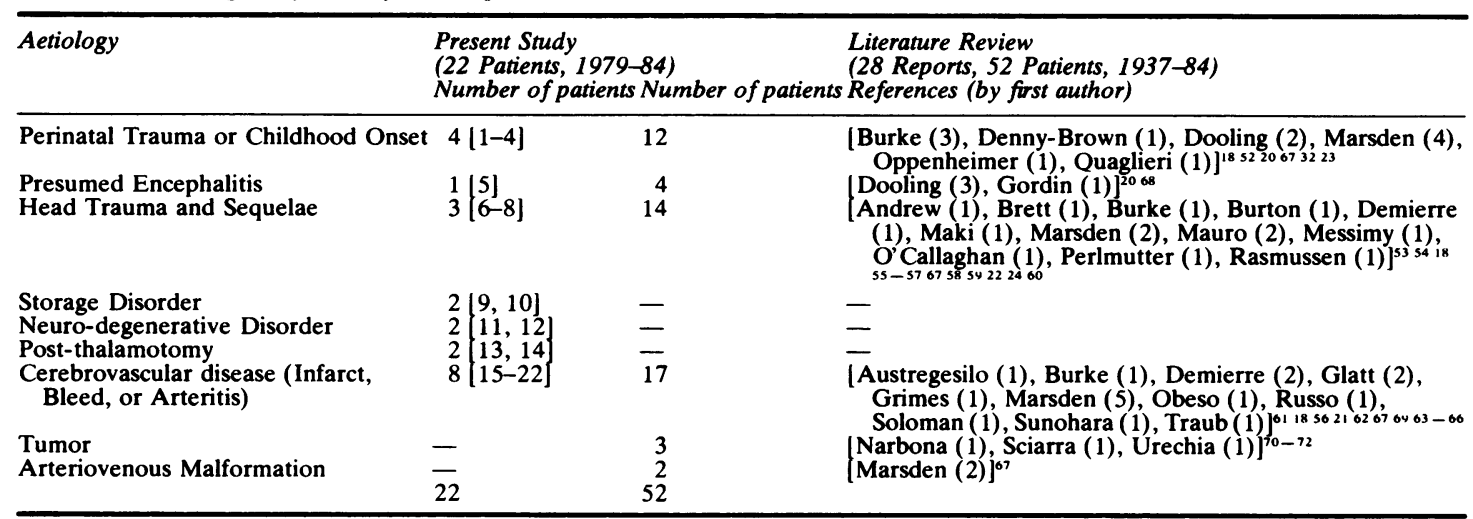


or at necropsy..$^{121-23}$ Perlmutter and Raichle found decreased oxygen metabolism and increased blood flow in the basal ganglia of a patient with hemidystonia who had a normal CT scan. ${ }^{24}$

Hemichorea and hemiballism are often confused with hemidystinia and have been attributed to contralateral, striatal and subthalamic pathology caused by infarction, haemorrhage, or metastatic tumour. ${ }^{25-27}$ In a review of 32 patients with hemiathetosis, 21 necropsy specimens were found to have destruction of the contralateral striatal or lenticular nuclei..$^{28}$

In our series, the most frequent cause of hemidystonia was haemorrhage or infarction in the basal ganglia (eight of 22 patients): patient $17 \mathrm{had}$ embolic occlusion of the right middle cerebral artery, patient 21 became hemiparetic during a migraine attack, and patient 22 . suffered a thalamicbasal ganglia haemorrhage, patient 18 probably developed hemidystonia from migrainous vascular occlusion, and the remaining four patients probably had thrombotic occlusions of arteries supplying the basal ganglia.

Dystonia is a rare complication of cerebrovascular disease in the basal ganglia territory. None of the $\mathbf{2 0}$ adult patients with CT-documented basal ganglia lesions reported by Naeser et $a^{29}$ and Damasio et a ${ }^{30}$ had hemidystonia. Graff-Radford and colleagues described five patients with thalamic infarction, two of whom had hemipareis with no associated dystonia. ${ }^{31}$ Posthemiplegic dystonia seems to occur more often in children than adults, possibly due to aberrant neuronal sprouting during brain maturation. ${ }^{20} 32$

Sparing of the corticospinal tract and disruption of the pathways between the striatum, pallidum, and thalamus are probably essential for secondary dystonia to occur. ${ }^{20}$ In our series, patients 16 and 21 had partial involvement of the corticospinal tract in the internal capsule on CT scan. All others had no apparent corticospinal involvement.

Patients 9 and 10 developed hemidystonia as a result of suspected ceroid lipofuscinosis, a heretofore unreported complication of this disease. These patients highlight the importance of a thorough search for storage disorders in all patients with atypical dystonia. Light and electron microscopy of peripheral lymphocytes or biopsy material taken from conjunctiva, skin, or rectum will usually establish the diagnosis. Sea-Blue histocytes may be seen on bone marrow biopsy. ${ }^{33}{ }^{34}$ It is possible that these two patients will eventually develop generalised dystonia, a more typical manifestation of the storage disorders. $^{35-38}$

Patient 11 presented with hemidystonia, peripheral neuropathy, and fasciculations suggesting motor neuron disease. His family history was unremarkable. Similar examples of "pallido-pyramidal" disorders manifesting as generalised dystonia, usually with autosomal dominant inheritance, were reviewed by Gilman and Romanul. ${ }^{39}$

Patient 12 had hemidystonia as a manifestation of Parkinson's disease. Dystonic postures of the hands and feet are frequently seen in patients with Parkinson's disease and with dopaminergic therapy ${ }^{40-42}$ Gortvai successfully treated 150 Parkinsonian patients with dystonia by stereotaxic thalamotomy. ${ }^{43}$ Patients 13 and 14 developed hemidystonia following thalamotomy for Parkinsonian tremor. Patient 14 represents one of two "cures" of hemidystonia reported in this series. He has been followed for 2 years after thalamotomy with no recurrence of dystonia.

Some of our patients had no predisposing brain injury and may eventually develop generalised idiopathic torsion dystonia. ${ }^{6144445}$ Marsden and Harrison estimated that maximal progression of generalised dystonia may take as long as 10 years. ${ }^{46}$ Generalised dystonia frequently begins as actioninduced focal dystonia, such as occupational cramp, ${ }^{47}$ whereas hemidystonia often starts at rest.

The response to medications was disappointing. Various muscle relaxants, tetrabenazine, and high dosage anticholinergic agents, ${ }^{6849}$ provided minimal or no improvement in motor performance. Fahn treated three hemidystonic adults and two children with up to $50 \mathrm{mg}$ of trihexyphenidyl or $800 \mathrm{mg}$ of ethopropazine per day with no success. ${ }^{48}$

Three patients underwent stereotaxic thalamotomy for treatment of hemidystonia, but obtained only mild or transient improvement. This is in contrast to reportedly successful results obtained in 12 patients with hemidystonia and 161 patients with dystonia musculorum deformans. ${ }^{50} \mathrm{si}$

We conclude that hemidystonia is often preceded by hemiparesis and that it usually implies a structural, degenerative or metabolic lesion of the contralateral basal ganglia. It is produced by a disconnection between the striatum and the thalamus with preservation of the corticospinal tract. A delay in onset of dystonia is commonly seen in patients with acute brain damage in childhood. Treatment is often disappointing, but favourable results may be obtained with medical or surgical therapy.

We thank Dr $R$ Nick Bryan for his review of neuroradiological studies.

\section{References}

' Oppenheimer $H$. Uber eine eigenartige Krampfkrankheit des kindlichen und jugendichen Alters (dysbasia 
lordotica progressiva, dystonia musculorum deformans). Neurol Zbl 1911;30:1090.

${ }^{2}$ Eldridge R. The torsion dystonias: literature review and genetic and clinical studies. Neurology (Minneap) 1970;20-2:1-78.

${ }^{3}$ Fahn S, Eldridge R. Definition of dystonia and classification of the dystonic states. Adv Neurol 1976;14:1-5.

${ }^{4}$ Fahn S. Torsion dystonia: clinical spectrum and treatment. Sem Neurol 1982;2:316-22.

${ }^{5}$ Fahn S. The varied clinical expression of dystonia. Neurol Clin 1984;2:541-54.

- Fahn S, Jankovic J. Practical management of dystonia. Neurol Clin 1984;2:555-70.

${ }^{7}$ Chase TN. Biochemical and pharmacologic studies of dystonia. Neurology (Minneap) 1970;20-2:122-30.

${ }^{8}$ Kartzinel R, Chase TN. Pharmacology of dystonia (chap. 3). In: Klawans HL, ed. Clinical Neuropharmacology (vol. 2). New York: Raven Press 1977:43-53.

' Zeman W. Pathology of the torsion dystonias (dystonia musculorum deformans). Neurology (Minneap) 1970;20-2:79-88.

${ }^{10}$ Zeman W. Dystonia: an overview. Adv Neurol 1976;14:91-103.

"Batshaw ML, Haslam RH. Multidisciplinary management of dystonia misdiagnosed as hysteria. Adv Neurol 1976;14:367-73.

12 Fahn S, Williams D, Reches A, et al. Hysterical dystonia, a rare disorder: report of five documented cases. Neurology (NY) 1983;33-2:161.

${ }^{13}$ Lesser RP, Fahn S. Dystonia: a disorder often misdiagnosed as a conversion reaction. Am J Psychiatry 1978; 135:349-52.

14 Marsden CD. The problem of adult-onset idiopathic torsion dystonia and other isolated dyskinesias in adult life (including blepharospasm, oromandibular dystonia, dystonic writer's cramp, and torticollis or axial dystonia). Adv Neurol 1976;14:259-76.

15 Burke RE, Fahn S, Jankovic J, et al. Tardive dystonia: late-onset and persistent dystonia caused by antipsychotic drugs. Neurology (NY) 1982;32:1335-46.

${ }^{16}$ Wolf ME, Killer WC. Tardive dystonia: controlled study of trihexyphenidyl treatment. Neurology (NY) 1984;34 (Suppl 1): 129.

${ }^{17}$ Mitchell SW. Post-paralytic chorea. Am J Med Sci 1974;68:342-52.

${ }^{18}$ Burke RE, Fahn S, Gold AP. Delayed-onset dystonia in patients with "static" encephalopathy. J Neurol Neurosurg Psychiatry 1980;43:789-97.

${ }^{19}$ Jankovic J, Patel SC. Blepharospasm associated with brainstem lesions. Neurology (NY) 1983;33:1237-40.

${ }^{20}$ Dooling EC, Adams RD. The pathological anatomy of posthemiplegic athetosis. Brain 1975;98:29-48.

${ }^{21}$ Glatt SL, Nausieda PA. Posthemiplegic dystonia: radiographic and pharmacologic analysis. Neurology (NY) 1984;34 (Suppl 1):290-1.

${ }^{22}$ O' Callaghan ED. Torsion dystonia complicating childhood hemiplegia. Med J Aust 1962;49:465-8.

${ }^{23}$ Quaglieri CE, Chun RW, Cleeland C. Movement disorders as a complication of acute hemiplegia of childhood. Am J Dis Child 1977;131:1009-10.

24 Perlmutter JS, Raichle ME. Pure hemidystonia with basal ganglion abnormalities on positron emission tomography. Ann Neurol 1984;15:228-33.

${ }^{25}$ Glass JP, Jankovic J, Borit A. hemiballismus and metastatic brain tumor. Neurology (NY) 1984;34:204-7.

${ }^{26}$ Goldblatt D, Markesbery W, Reeves AG. Recurrent hemichorea following striatal lesions. Arch Neurol 1974;31:51-4.

${ }^{27}$ Kase CS, Maulsby GO, de Juan E, Mohr JP. Hemichorea-hemiballism and lacunar infarction in the basal ganglia. Neurology (NY) 1981;31:452-5.

${ }^{28}$ Carpenter MB. Athetosis and the basal ganglia. Arch Neurol 1950;63:875-901.

${ }^{29}$ Naeser MA, Alexander MP, Helm-Estabrooks N, et al. Aphasia with predominantly subcortical lesion sites: description of three capsular/putaminal aphasia syndromes. Arch Neurol 1982;39:2-14.

${ }^{30}$ Damasio AR, Damasio H, Rizzo M, et al. Aphasia with nonhemorrhagic lesions in basal ganglia and internal capsule. Arch Neurol 1982;39:15-20.

${ }^{31}$ Graff-Radford NR, Eslinger PJ, Damasio AR, Yamada $T$. Non-hemorrhagic infarction of the thalamus: behavioural, anatomic, and physiological correlates. Neurology (NY) 1984;34:14-23.

${ }^{32}$ Oppenheimer DR. A case of striatal hemiplegia. $J$ Neurol Neurosurg Psychiatry 1967;30:134-9.

${ }^{33}$ Swaiman KF, Gang BP, Lockman LA. Sea-blue histiocytes and posterior column dysfunction: a familial disorder. Neurology (Minneap) 1973;25:1084-7.

${ }^{34}$ Swaiman KF, Smith SA, Trock GL, Siddiqui AR. Seablue histiocytes, lymphocytic cytosomes, movement disorder, and ${ }^{59} \mathrm{Fe}$-uptake in basal ganglia: Hallervorden-Spatz disease or ceroid storage disease with abnormal isotope scan? Neurology (NY) 1983;33:301-5.

${ }^{35}$ Goldman JB, Katz D, Rapin I, et al. Chronic GM gangliosidosis presenting as dystonia: I. Clinical and pathological features. Ann Neurol 1981;9:465-75.

${ }^{36}$ Karpati G, Carpenter S, Wolfe LS, et al. Juvenile dystonic lipidosis: an unusual form of neurovisceral storage disease. Neurology (Minneap) 1977;27:32-42.

${ }^{37}$ Kobayashi T, Suzuki K. Chronic GM gangliosidosis presenting as dystonia: II. Biochemical studies. Ann Neurol 1981;9:476-83.

${ }^{38}$ Longstreth WT Jr, Daven JR, Farrell DF, et al. Adult dystonic lipidosis: clinical, histologic, and biochemical findings of a neurovisceral storage disease. Neurology (NY) 1982;32:1295-9.

${ }^{39}$ Gilman S, Romanul FC. Hereditary dystonic paraplegia with amyotrophy and mental deficiency: clinical and neuropathological characteristics (chap. 19). In: Vinken PJ, Bruyn GW, eds. Handbook of Clinical Neurology (vol. 22). Amsterdam: North-Holland 1975:445-65.

${ }^{40}$ Duvoisin RC, Yahr MD, Lieberman J, et al. The striatal foot. Trans Am Neurol Assoc 1972;97:267.

41 Jankovic J. Management of motor side effects of chronic levodopa therapy. Clin Neuropharmacol 1982;51:519-28.

42 Nausieda PA, Weiner WJ, Klawans HL. Dystonic foot response in Parkinsonism. Arch Neurol 1980; 37: 132-6.

${ }^{43}$ Gortvai P. Deformities of the hands and feet in Parkin- 
sonism and their reversibility by operation. J Neurol Neurosurg Psychiatry 1963;26:33-6.

${ }^{44}$ Marsden CD, Harrison MJB, Bundy S. The natural history of idiopathic torsion dystonia. Adv Neurol 1976;14:177-86.

45 Marsden CD. The focal dystonias. Sem Neurol 1982;2:324-33.

${ }^{46}$ Marsden CE, Harrison MJG. Idiopathic torsion dystonia (dystonia musculorum deformans): a review of 42 patients. Brain 1974;97:793-810.

${ }^{47}$ Sheehy MP, Marsden CD. Writer's cramp-a focal dystonia. Brain 1982;105:461-80.

${ }^{48}$ Fahn S. High dosage anticholinergic therapy in dystonia. Neurology (NY) 1983;33:1255-61.

${ }^{49}$ Jankovic J. Tetrabenazine in the treatment of hyperkinetic movement disorders. In: Fahn S, Calne D, Shoulson I, eds. Experimental Therapeutics of Movement Disorders. New York: Raven Press 1983:277-89.

${ }^{50}$ Andrew J, Fowler CJ, Harrison MJG. Stereotaxic thalamotomy in 55 cases of dystonia. Brain 1983; 106:981-1000.

${ }^{51}$ Cooper IS. Twenty-year follow-up study of the neurosurgical treatment of dystonia musculorum deformans. Adv Neurol 1976;14:432-52.

s2 Denny-Brown D. Focal lesions of the basal ganglia (chap. III). The basal ganglia. London: Oxford University Press 1962:55-65.

${ }^{53}$ Andrew J, Fowler CJ, Harrison MJG. Hemidystonia due to focal basal ganglia lesion after head injury and improved by stereotaxic thalamotomy. $J$ Neurol Neurosurg Psychiatry 1982;45:276.

${ }^{54}$ Brett BM, Hoare RD, Sheehy MP, Marsden CD. Progressive hemidystonia due to focal basal ganglia lesion after mild head trauma. J Neurol Neurosurg Psychiatry 1981;44:460.

s5 Burton K, Farrell K, Li D, Calne DB. Lesions of the putamen and dystonia: $\mathrm{CT}$ and magnetic resonance imaging. Neurology (NY) 1984;34:962-5.

56 Demierre B, Rondot P. Dystonia caused by putaminocapsulo-caudate vascular lesions. J Neurol Neurosurg Psychiatry 1983;46:404-9.

57 Maki Y, Akimoto H, Enomoto T. Injuries of basal ganglia following head trauma in children. Child's Brain 1980; 7:113-23.
${ }^{58}$ Mauro AJ, Fahn S, Russman B. hemidystonia following “minor" head trauma. Ann Neurol 1980;8:108.

${ }^{59}$ Messimy R, Diebler C, Metzger J. Dysonie de torsion du membre superieur gauche, probablement consecutive a un traumatisme cränien. Rev Neurol (Paris) 1977;133-3:199-206.

${ }^{60}$ Rasmusson K, Fabian RH. Posttraumatic focal dystonia. Neurology (NY) 1984;34 (Suppl 1):171.

${ }^{61}$ Austregesilo A, Borges-Forte A. Sur un cas d' hémichorée avec lésion du noyau caudé. Rev Neurol (Paris) 1937;4:477-88.

${ }^{62}$ Grimes JD, Hassan MN, Quarrington AM, D' Alton J. Delayed-onset posthemiplegic dystonia: CT demonstration of basal ganglia pathology. Neurology (NY) 1982;32:1033-5.

${ }^{63}$ Russo LS, Jr. Focal dystonia and lacunar infarction of the basal ganglia. Arch Neurol 1983;40:61-2.

o4 Soloman GE, Engel M, Hecht HL, Rapoport AR. Progressive dyskinesia due to internal cerebral vein thrombosis. Neurology (NY) 1982;32:769-72.

${ }^{65}$ Sunohara N, Mukoyama M, Mano Y, Satoyoshi E. Action-induced rhythmic dystonia: an autopsy case. Neurology (NY) 1984;34:321-7.

${ }^{66}$ Traub M, Ridley A. Focal dystonia in assocition with cerebral infarction. J Neurol Neurosurg Psychiatry 1982;45:1073-7.

${ }^{67}$ Marsden CD, Obeso JA, Zarranz JJ, Lang AE. The anatomical basis of symptomatic hemidystonia. Brain (in press).

${ }^{68}$ Gordin R. A case of unilateral torsion-dystonia. J Nerv Ment Dis 1939;90:344-57.

${ }^{64}$ Obeso JA, Martinez-Vila E, Delgado G, et al. Delayed onset dystonia following hemiplegic migraine. Headache (in press).

${ }^{70}$ Narbona J, Obeso JA, Tun̈on T, et al. Hemi-dystonia secondary to localized basal ganglia tumour. J Neurol Neurosurg Psychiatry 1984;47:704-9.

"Sciarra D, Sproflein BE. Symptoms and signs referable to the basal ganglia in brain tumor. Arch Neurol 1953;69:450-61.

72 Urechia CI, Dragomir L, Usinievici G. Spasme de torsion unilatéral causé par une tumeur cérébrale. Confun Neurol 1943;5:271-80. 